\title{
Investigation of Physical Education Teachers' Altruism Features
}

\author{
Şıhmehmet YİĞİT ${ }^{1}$ \& Eyüp ACAR ${ }^{2}$ \\ ${ }^{1}$ School of Physical Education and Sports, Namik Kemal University, Turkey \\ ${ }^{2}$ Ministry of Education, Turkey \\ Correspondence: Şıhmehmet YİĞìT, School of Physical Education and Sports, Namik Kemal University, Turkey. \\ E-mail: syigit@nku.edu.tr
}

Received: March 23, 2020

Accepted: April 25, $2020 \quad$ Online Published: June 28, 2020

doi:10.5539/ies.v13n7p177

URL: https://doi.org/10.5539/ies.v13n7p177

\begin{abstract}
Purpose of the research: it is aimed to examine whether the levels of altruism of Physical Education and sports teachers differ according to some variables. This research consists of a total of 126 teachers, 35 women and 91 men, who work as physical education and sports teachers at primary education secondary grade and secondary schools in Kütahya province. In the research, 'Personal Information Form' developed by the researcher and the 20-item Altruism scale, which consists of two factors and was formed by Ersanlı and Çabuker (2015) with the aim of developing a measurement tool that can measure the individual's level of altruism and that is suitable for Turkish society and culture. In reliability validity analysis, Cronbach Alpha internal consistency coefficient was found as $\alpha=$.76. The analysis related to the questionnaire form used in the research and the scale was done through the SPSS 22 program. Mann-Whitney U test and Kruskal Wallis test were conducted for more than two independent sample groups. As a result of the research; when the results were analyzed according to gender, age, place of duty, school type, year variables of teachers working as physical education and sports teachers, no significant difference was seen due to the high level of teachers' altruism points.
\end{abstract}

Keywords: education, teacher, altruism

\section{Introduction}

It is possible to see the definitions of altruism as different terms in many fields of education and other social sciences. While solidarity and helping are defined as altruism, 'being altruist', altruist is defined as 'trying to be useful to someone without personal benefit' (TDK). The main task has been attributed to helping others by ignoring our own interests. While altruism was as old as human history, studies related to altruism began when people's attitude and understanding of helping people in the murder of Kitty Genovese surprised several social scientists (Bilgin, 1988). Undoubtedly, the human is at the top step of the world of beings. The correct existence of man and maintaining his existence healthily depend on the communication and interaction with each other and the others. The communication network of people with each other is based on the qualities that make people human and acquires quality. The features that make people human come from the principle of 'to exist to exist'. The essence of this principle is to love, to respect, not to marginalize, to share, to realize its responsibilities in this regard and to fulfil its needs on the ground of tolerance. When all these are taken into consideration, we can say that the essence of the point is to give willingly, that is, altruism (Ersanl1, 2012). First of all, in order to reveal the most basic definition, the definition in the Turkish Language Institution dictionary should be addressed. Considering this definition, it is seen that altruism has two main features: to be helpful/help others, not to expect rewards/benefits/interests for yourself. In the next definitions, analysis was made on the basis of the features apart from these two basic features. Altruism as the term of education "(1) moral attitude and view that adopts sacrifice as a principle for the sake of others, regardless of interest; (2) The moral view of A. Comte and Spencer, based on the idea that each person's main obligation is to devote himself to others, to society " (Oğuzkan, 1974). When it is considered as the term of philosophy, it is seen that it has the definition of "the view that makes the principle of living and acting for the good of others" (Akarsu, 1975). A more philosophically more detailed definition is Cevizci's (1999) definition.

The definition is as follows: "loving people without interest, an attitude of one to dedicate himself to the welfare and general well-being of other people and society, the moral understanding that underpins the well-being of others, emphasizes being benevolent, tolerant and helpful towards other people, suggests to behave according to 
the formula of living for someone else: as an opinion against selfishness and individualism, the doctrine, which states that an individual should dedicate himself to the needs and interests of others without any interest. From this definition, it is seen that altruism is associated with values of goodwill, benevolence and tolerance. When examined from a sociological point of view, it should be stated firstly that the concept of altruism was born with sociology, but research has progressed in different fields (Karadağ \& Mutafçılar, 2009). In terms of sociological definition, "the pioneers of sociology have defined altruism as a tendency or desire (Comte) for others to act voluntarily without personal interest (Durkheim)" (Topses, 2012). It also has a sociological definition in the glossary of sociological terms referred to by the Turkish Language Institution as "being ready to give up personal interests for others' benefit, to help others with selfless motives (Ozankaya, 1975). Based on these definitions, getting beyond thinking personal benefit and giving up personal interests can be added to the features of altruism. The definition of the altruism value in terms of educational sciences is as follows: "Morality attitude and view that adopts self-sacrifice as a principle for the good of others regardless of interest" (Oğuzkan, 1974). When people behave, they make two kinds of choices. They either work for their own interests or make the choice that can benefit other people without thinking of themselves. The first of these is egoism and the other type of behaviour is accepted as altruism (Ylldiz et al., 2012). Altruism, which includes many positive social behaviors such as helping, sacrifice, taking responsibility, donating, shows itself in every area of life (Akbaba, 1994). Organizational citizenship behavior is also defined by Organ (1988) as voluntary or extraordinary behaviours that are not directly or identified in the official reward system and contribute to the organization as a whole. Altruism is also acceptable as one of the moral principles. Helping covers moral principles of helping, helping people is one of conscience and religious duties.

\section{Materials and Methods}

It consists of a total of 126 people, 35 of whom are women and 91 are men who work as physical education and sports teachers working in the city of Kütahya.

\section{Data Collection}

First of all, the current information about the purpose of the research was systematically given by reviewing the literature. Thus, a theoretical framework was created on the subject. The Personal Information form prepared by the researcher to determine the demographic characteristics was developed by Ersanlı and Çabuker (2015) to develop a measurement tool suitable for the Turkish society and culture that can measure the individual's level of altruism.

The reliability study was conducted on the data obtained from the sample group of 369 participants and the sample group of 271 participants. According to the analysis on the data obtained from 369 participants, the internal consistency coefficient of the scale was found as $\alpha=.89$.In the reliability analysis on the sample of 271 people, Cronbach Alpha internal coefficient of consistency was found as $\alpha=.76$. Reliability values according to factors for self-sacrifice and selfishness factors are relatively .87 and .77.Accordingly, the scope validity and construct validity studies were carried out in accordance with the scale development steps, and the validity and reliability of the scale were determined with the data obtained from 369 students for exploratory factor analysis and 271 students for confirmatory factor analysis. Exploratory factor analysis results showed that the scale has a two-factor structure.

Fifteen items collected in the first factor were collected under the title of "devotion", and five items collected in the second factor were collected under the title of "selfishness". The contribution of the1st factor to the explained total variance is $34.51 \%$, and that of the 2 nd factor is $8.455 \%$. The total variance explained by the 20 -item scale consisting of two factors is $42.967 \%$. Whether the two-factor scale structure showed similar results in different samples was evaluated by confirmatory factor analysis. In line with the obtained fit indices, as a result of the confirmatory factor analysis, it is seen that the structure of the two-factor scale gives acceptable and valid results. It was concluded that the scale has structural validity because the values were statistically significant, the error variances were low and the factor load values were high. The lowest score that can be obtained from altruism scale obtained as a result of the necessary validity and reliability analysis is -10 and the highest score is 70 .The lowest and highest scores that can be obtained on the basis of factors are respectively 15-75 for the $1^{\text {st }}$ factor and5-25 for the $2^{\text {nd }}$ factor. As the contents of these two factors are taken into account, the individual's level of altruism is determined by subtracting two factor total scores from each other.

\section{Data Analysis}

The data analysis related to the questionnaire form used in the research as a result of the scale application and to the scale was made through using the SPSS 22 program. Firstly, some tests were carried out to determine whether the dataset was normally distributed. The normality tests of the data set are understood by looking at the 
Kolmogorov-Simirnov and Shapiro Wilk tests. Shapiro Wilks test is used when the number of observations is less than 29, and Kolmogorov-Simirnov (Lilliefors) test is used when the number of observations is more than 29 (Kalayc1, 2008). Since the number of data is 126, the results of the Kolmogorov-Simirnov (Lilliefors) test were examined, and in-group comparisons, the number of some groups was below 29 and both values were examined. In both values, the significance value of the altruism level data was obtained as 0.000 .

Since the data set does not conform to normal distribution, the Mann-Whitney U test (Büyüköztürk, 2005), which tests whether the scores obtained from two independent samples differ significantly from each other, was applied to the Kruskal Wallis test for more than two independent sample groups.

\section{Findings}

Finding analyses obtained in this part of the study are presented in a table and interpreted.

Table 1. Descriptive statistics information of physical education teachers participating in the research

\begin{tabular}{cccccc}
\hline Variables & Groups & Frequency & Percentage $\%$ & Min. score & Max. Score \\
\hline \multirow{4}{*}{ Gender } & Male & 91 & 72.2 & 8 & 70 \\
& Female & 35 & 27.8 & -9 & 70 \\
& Total & 126 & 100 & -9 & 70 \\
& $23-30$ & 25 & 19.8 & 36 & 70 \\
Age & $31-40$ & 57 & 45.2 & -9 & 70 \\
& $41+$ & 44 & 34.9 & 8 & 70 \\
& Total & 226 & 100 & -9 & 70 \\
\multirow{5}{*}{ Work Location } & District & 50 & 39.7 & 27 & 70 \\
& Province & 76 & 63.3 & -9 & 70 \\
& Total & 126 & 100 & -9 & 70 \\
& School Degree & 58 & 46.0 & -9 & 70 \\
& High school & 68 & 54.0 & 8 & 70 \\
& Total & 126 & 100 & -9 & 70 \\
& $1-5$ & 30 & 23.8 & 36 & 70 \\
Year of Seniority & $6-10$ & 39 & 31.0 & 27 & 70 \\
& $11+$ & 57 & 45.2 & -9 & 70 \\
& Total & 126 & 100 & -9 & 70 \\
\hline
\end{tabular}

According to the descriptive statistical data of the research, the physical education teachers who participated in the research consisted of a total of 126 people, $72.2 \%$ of them were men and $27.8 \%$ of them were women. When we look at the age ranges, $19.8 \%$ of them are between the ages of $23-30,45.2 \%$ of them are between the ages of $31-40$ and $34.9 \%$ of them are between the ages of 41 and over. According to the work place, $39.7 \%$ of them work in district and $63.3 \%$ of them work in province. According to the degree of school they work, $46.0 \%$ of them work in secondary school, $54.0 \%$ of them work in high school. When we look at the year of seniority, it is seen that $23.8 \%$ of them have been working for 5 years, $31.0 \%$ of them have been working for $6-10$ years and $45.2 \%$ of them have been working for 11 years or more.

Table 2. The results of Mann-Whitney U test between the total scores of altruism scale of physical education teachers according to gender variable

\begin{tabular}{ccccccc}
\hline Gender & $\mathrm{N}$ & Rank Avg. & Rank Top. & $\mathrm{U}$ & $\mathrm{Z}$ & $\mathrm{P}$ \\
\hline Male & 91 & 63.39 & 5768.50 & \multirow{2}{*}{1582.50} & -.055 & .957 \\
Female & 35 & 63.79 & 2232.50 & & & \\
\hline
\end{tabular}

When the table is analyzed, according to the survey conducted to determine the level of altruism, which consists of two parts as self-sacrifice and selfishness, the sum of self-sacrifice scores is calculated as the selfishness score. Since the dedication score is minimum 15 maximum 75, the ego score is minimum 5 maximum 25, we can say that the one with the highest altruism level will be 70 and the lowest will be -10.In the table, we can say that the altruism level of physical education teachers is quite high, considering the highest score is 70 according to the mean data of Male and Female. In terms of gender variable of physical education teachers, there is no significant 
difference between altruism scores $\mathrm{p}>0.05$.

Table 3. Kruskal-Wallis test results among the total scores of altruism scale of physical education teachers according to age variable

\begin{tabular}{cccccc}
\hline Age & $\mathrm{N}$ & Rank Avg. & $\mathrm{X}^{2}$ & $\mathrm{df}$ & $\mathrm{p}$ \\
\hline $23-30$ & 25 & 53.82 & & & \\
$31-40$ & 57 & 68.32 & 2.777 & 2 & .249 \\
$41+$ & 44 & 62.75 & & & \\
\hline
\end{tabular}

When the table is analyzed, there is no significant difference between altruism total scores of physical education teachers in terms of age variable $\mathrm{p}>0.05$.

Table 4. Mann-Whitney U test results between altruism scale total scores of physical education teachers according to the duty place variable

\begin{tabular}{ccccccc}
\hline Work Location & $\mathrm{N}$ & Rank Avg. & Rank Tp. & $\mathrm{U}$ & $\mathrm{Z}$ & $\mathrm{p}$ \\
\hline District & 50 & 59.51 & 2995.50 & \multirow{2}{*}{1720.5} & -.896 & .370 \\
Province & 76 & 65.86 & 5005.50 & & & \\
\hline
\end{tabular}

When the table is analyzed, there is no significant difference between altruism total scores of physical education teachers in terms of work location variable $\mathrm{p}>0.05$.

Table 5. Results of Mann-Whitney U test between the total scores of altruism scale of physical education teachers according to the school type variable

\begin{tabular}{ccccccc}
\hline Type of School & $\mathrm{N}$ & Rank Avg. & Rank Top. & $\mathrm{U}$ & $\mathrm{Z}$ & $\mathrm{P}$ \\
\hline Secondary School & 58 & 58.02 & 3365.0 & \multirow{2}{*}{1654} & -1.558 & .119 \\
High school & 68 & 68.18 & 4636.0 & & & \\
\hline
\end{tabular}

When the table is analyzed, there is no significant difference between the altruism scores of physical education teachers in terms of school type variable $\mathrm{p}>0.05$.

Table 6. Kruskal-Wallis test results among the total scores of altruism scale of physical education teachers according to the seniority year variable

\begin{tabular}{cccccc}
\hline Year of Seniority & $\mathrm{N}$ & Rank Avg. & $\mathrm{X}^{2}$ & $\mathrm{df}$ & $\mathrm{P}$ \\
\hline 1-5 years & 30 & 56.15 & & & \\
6-10 years & 39 & 68.50 & 1.960 & 2 & .375 \\
$11+$ & 57 & 63.95 & & & \\
\hline
\end{tabular}

When the table is analyzed, there is no significant difference between altruism scores of physical education teachers in terms of seniority year variable $\mathrm{p}>0.05$.

\section{Discussion and Conclusion}

The universe of the study was reviewed and the related literature was researched and the result was interpreted and evaluated. In order to measure the effect on altruism levels in the research, when the results were analyzed according to gender, age, duty place, school type, year variables of teachers working as physical education and sports teachers, there was no significant difference due to the high level of teachers' altruism.

When it is analyzed by gender, which is one of the variables examined in the study, it is seen that women have higher levels of altruism than men. Some studies (Furco, 1996) emphasize that altruism is inherent in volunteering, one of the types of experiential education that is usually service oriented. While it was observed that there was no difference between the gender, sports status, disability degree, education and sports branch and self-level of the hearing impaired, there was a relationship between incomes and self-esteem levels. İşmen and Yıldız (2005) state 
that in their study named "Investigation of Attitudes Towards Teaching in Terms of Altruism and Assertiveness Levels", women have higher altruism scores than men. In the study conducted by Polat and Celep (2008), it was determined that teachers' perceptions about their personal characteristics (gender, age, seniority, branch, duration of service in the last school they worked at) and school characteristics (school type, number of teachers in school) did not make any significant difference in teachers' perceptions of organizational citizenship behavior and behaviors in their sub-dimensions. In another study, it was observed that none of the teacher candidates had negative effects on the altruism value during seven-week period, and that there were positive impacts from the first week and even in some weeks there was a high level of impact. The point to be noted here is not that teacher candidates did not experience any problems in the process, but that there were not any negative effects on their altruism values. As Marchel (2003) emphasizes, the challenging moments in the service experiences are essential for the development of altruism. In the results related to social problem solving skill, it was stated that teacher candidates encountered many problems. This study, like Marchel's (2003) study, gave important clues that there is a real positive impact on altruism in these problems. Altruism motivation can be defined as "the desire to increase the well-being of others, even though it has harm to one's own well-being"; altruism behaviour can also be defined as "an action of an altruism motivation that provides sufficient reason" (Elster, 2007). It has been observed that individuals with self-concept have a lower level of making mistakes and exhibiting aggressive attitude (Yiğit, Y1lmaz, Acar, \& Dalbudak, 2019).

According to Wangyal (2001), although altruism should be effective in conveying traditional values such as duty, responsibility and reciprocity, modern education is not enough to convey these values. The change that comes with modernization has damaged traditional values. As a result, the literature was examined and it was revealed that the results showed parallelism in the same direction.

\section{References}

Akarsu, B. (1975). Felsefe terimleri sözlüğ̈̈̈. Ankara: Türk Dil Kurumu Yayınları.

Akbaba, S. (1994). Grupla psikolojik danısmanın sosyal psikolojik bir kavram olan özgecilik üzerindeki etkisi. Yayımlanmamış. Doktora Tezi, Atatürk Üniversitesi, Erzurum.

Bilgin, N. (1988). Sosyal Psikolojiye Giriş. İzmir: Ege Üniversitesi Edebiyat Fakültesi.

Büyüköztürk, Ş. (2005). Sosyal bilimler için veri analizi el kitabı. Ankara: Pegem yayıncılık.

Cevizci, A. (1999). Felsefe sözlü̆̈̈̈. İstanbul: Paradigma Yayınları

Comte, A. (1875). System of positive polity (çev. J. H. Bridges). London: Spottiswoode and Co. (Orijinal çalışmanın basım tarihi 1851).

Elster, J. (2007). Sosyal Davranışı Açılklamak. Çev. Olcay Sevimli ve Macide Ö. Karaduman, Ankara: Phoenix Yay.

Ersanlı, K. (2012). Düşündüklerim Paylaştıklarım. Samsun: DH Yayın.

Ersanlı, K., \& Çabuker, D. N. (2015). Diğerkâmlık Ölçeğinin psikometrik özellikleri. Elektronik Sosyal Bilimler Dergisi, 14(52), 43-53. https://doi.org/10.17755/esosder.70589

Furco, A. (1996). Service-learning: A balanced approach to experiental education. In B. Taylor (Ed.), Expanding Boundaries: Service and Learning (pp. 1-6). Columbia: Taylor Design and Publishing.

İşmen, A. E., \& Yıldız, S. A. (2005). Öğretmenliğe İlişkin Tutumların Özgecilik ve Atılganlık Düzeyleri Açısından İncelenmesi. Kuram ve Uygulamada EğitimYönetimi, 42(42), 151-166.

Kalayci, Ş. (2008). SPSS Uygulamalı çok Değişkenli İstatistik Teknikleri. Ankara: Asil Yayın Dağıtım.

Karadağ, E., \& Mutaf̧̧ılar, I. (2009). Prososyal davranış ekseninde özgecilik üzerine teorik bir çözümleme. Felsefe ve Sosyal Bilimler Dergisi, 8, 41-70.

Marchel, C. A. (2003). The path to altruism in service-learning classes: Big steps or a different kind of awkwardness? Michigan Journal of Community Service Learning, 10(1), 15-27.

Oğuzkan, F. (1974). Eğitim terimleri sözlüğü. Ankara: Türk Dil KurumuYayınları.

Organ, D. W. (1988). Organizational Citizenship Behavior: The Good Soldier Syndrome. Lexington Books/DC Heath and Com.

Ozankaya, Ö. (1975). Toplumbilim terimleri sözlüğ̈̈. Ankara: Türk Dil Kurumu Yayınları.

Polat, S., \& Celep, C. (2008). Orta öğretim öğretmenlerinin örgütsel adalet, örgütsel güven, örgütsel vatandaşlık davranışlarına ilişkin algıları. Kuram ve Uygulamada Egitim Yönetimi Dergisi, 14(2), 307-331. 
Topses, G. (2012). Elseverlik (alturizm) ve benseverlik (egoizm) ölçeğiyle ilgili geçerlik ve güvenirlik çalışması. International Journal of New Trends in Arts, Sports \& Science Education, 2, 60-71.

Wangyal, T. (2001). Ensuring Social Sustainability: Can Bhutan's Education System Ensure Intergenerational Transmission of Values? Journal of Bhutan Studies, 3(1), 106-111.

Yiğit, Ş., Yılmaz, T., Acar, E., \& Dalbudak, İ. (2019). An investigation of self and aggression levels of weightlifters. International journal of applied exercise physiology, 8(3), 2322-3537.

Yıldız, S., Taştan, B., İlknur, Y., \& Bahadır, F. (2012). Kişilik Tipi ile Olumlu Sosyal Davranış Arasındaki İlişki: Marmara Üniversitesi Öğrencileri Üzerinde bir Araştırma. Atatürk Üniversitesi İktisadi ve İdari Bilimler Dergisi, 26(1), 215-233.

\section{Copyrights}

Copyright for this article is retained by the author(s), with first publication rights granted to the journal.

This is an open-access article distributed under the terms and conditions of the Creative Commons Attribution license (http://creativecommons.org/licenses/by/4.0/). 